\title{
How CPS version 2.2 can improve students' activity and achievement in integrated learning towards the second grade students of primary school
}

\author{
S. D. Handaryati, W. Sukartiningsih, W. T. Subroto \\ Universitas Negeri Surabaya \\ Surabaya, Indonesia \\ vitta_sevita@ymail.com
}

\begin{abstract}
This study aims to improve student activity and knowledge-skill achievement in integrated learning. This is a classroom action research which applied CPS Version 2.2 to solve social problems related to students' behavior on clean and healthy life. Data collection used documentation, observation, and test methods while the analysis techniques used descriptive statistical analysis. The result showed 1) Students' activity increased in each cycle from their process to find a fact, problem, idea, solution, acceptance involving visual, oral, listening, writing, and motoric activity; 2) Achievement increased at both domains. The success indicator in cycle 3 was equal to $\geq 80 \%$, and average achievements were above the determined minimal classical end (75). The improvement of students' knowledge competency through social problem solving around students' contextual environment implemented in action to carry out the solution right away, therefore, students' competency can be improved as a proof of awareness and caring autonomously.
\end{abstract}

Keywords : CPS Version 2.2 ; student activity and achievement; integrated learning toward

\section{INTRODUCTION}

Based on the background of problems such as the low ability of second grade students in behaving on clean and healthy life which was observed through the students' daily activities, students' competence on these issues was not wellintegrated with their developed skills. When the product (learning outcome) is not as expected, there is a problematic learning process, in this case is the improvement of students' learning activities. When what is expected is a concrete form of student action observed by the teacher, then the improvements are made to subtheme within the school context. Therefore, this research attempts to overcome some problems such as low student activity in the learning process and achievement on knowledge and skill domains referring to basic competence in Curriculum 2013.

Creative Problem Solving (CPS) was developed by Alex Osborn and Sidney Parnes. Mitchell and Kowalik (1999) defined CPS as a process, method or problem approach system which uses imaginative ways and produces effective action. CPS model is a learning model centered on problem-solving skills, followed by strengthening skills as a form of student creativity. CPS is a problem-solving learning model that emphasizes the discovery of alternative ideas or ideas to find the most efficient solutions to of a problem by using a divergent and convergent thinking process during the implementation of the solution. Potential solutions will be accepted.

Treffinger and Isaken (2005) concluded that there is a change implication in the CPS framework for teaching and learning in the form of instruction and assessment on education. Referring to the CPS Version 2.2 (Treffinger and Isaken, 2004), an instructional program used the A-5 Stages Process model in diamond series with the development of divergent and convergent thinking in the process stages. The application of the CPS model in this study uses five phases referring to CPS Version 2.2 by Parnes and Noller with some adaptation and adjustment to the context of second grade students of a primary school by using the picture media to help students have provision to pass each stage.

The application of the CPS Version 2.2 is led by social problems about healthy and clean living behaviors at schools. There is the focus of the study on the topic of contextual issues for students which is more specific. Then coming to CPS model syntax: Phase I (Fact Finding), Phase II (Problem Finding), Phase III (Idea Finding), Phase IV (Solution Finding), and Phase V (Acceptance Finding). Followed by the implementation of solutions, reflection, and evaluation.

Fogarty (1991) mentioned ten integrated learning models: fragmented, connected, nested, sequenced, shared, webbed, threaded, integrated, immersed, and networked. The integrated learning used in this research is more inclined to the integrated model. This model views the curriculum as a kaleidoscope that interdisciplinary topics of science are structured to include overlapping concepts of designs and emerging pattern implemented by combining four subjects (interdisciplinary) and establishing priority of interrelated subject matter, skills, concepts, and attitudes in some subjects. This research used five subjects with two priority.

The implementation of CPS Version 2.2 utilized the picture media as a supporting tool in the readiness phase of students to pass each stage of learning with the CPS model of social problems contextually. Gagne (in Karti Soeharto, 2003:98) stated that the media are the various types of components in a students' environment that can stimulate students to learn. 


\section{METHOD}

The classroom action research carried out using a model developed by Kemmis and Taggart (1988:11) with repetitive and continuous cycles (spiral cycles) ranging from planning, action, observation, to reflection.

The subjects were all second grade students in one class consisting of 15 male and 15 female students at SDN Ketintang I/409 Surabaya. The implementation of this research began by collecting data in the form of observation and interview since the first semester. Then the study had been conducted for \pm 1 month in the second semester in the academic year of 2016/2017. The data collected using documentation, observation, and test methods. Data analysis techniques used descriptive statistical analysis.

In the research conducted, the researcher also acted as a model teacher. The collaborator was a classroom teacher as an observer I and assisted by a colleague as observer II. The test was done at the end of each cycle. The instrument used was a written test in the form of problem-based by analyzing images associated with various cognitive thinking processes of students. The written test was the result of learning achievement of knowledge competence after applying CPS Version 2.2. While practice test to measure students' skill competence used observation method with observation achievement rubric of students' skill competence. The range of quantitative values was 1-5 referring to the criteria that had been described in each value achievement. The value was converted to a range of $0-100$ as the value of the student's skill. Documentation is an attempt to give an idea of how a classroom action research was done. Documenting activities carried out by taking pictures of the activities of students in the implementation of learning when the study was conducted.

The main purpose of this study was to improve students' activity and achievement through CPS Version 2.2. The data analysis technique used was descriptive statistical analysis. Data analysis conducted in this study on student activity was the percentage of average appearance of indicators on each aspect of observation that was interpreted as successful in the learning process if the student activity achieved $\geq 80 \%$.

Quantitative-qualitative data analysis of student achievement was obtained from the results of written tests and practical tests. The tests were conducted with the aim of knowing the achievement of students' knowledge and skill competencies as a result of students' achievement referring to the basic competence of knowledge and skill in Curriculum 2013 for the second grade of primary school.

Practice tests carried out at the time of implementation of solutions that students found in the acceptance phase. The written test for each individual was done at the end of the cycle. The data were calculated using the achievement of a class average of the classical end. Achievements obtained were interpreted as the indicator of the success of the study set that is the completeness of the value of students in learning if it reached the value $\geq 75$. While the classical end was said to be achieved if students who achieve the minimum value $\geq$ $80 \%$ of all students in the class.

\section{RESULT AND DISCUSSION}

\subsection{Student Activity}

The results of this study showed that the implementation of CPS Version 2.2 can improve student activity. Based on the research results obtained, the students' activity from Cycle I to Cycle III always increased. Students' activity from Cycle I to Cycle II increased by $7.07 \%$. Students' activity in Cycle II, when compared to Cycle III has increased by $4.16 \%$.

Indicators of successful students' activity in the learning process applying CPS Version 2.2 appeared from student activities in the process of finding a fact, problem, idea, solution, and acceptance. Students' activity in Cycle III reached $85.56 \%$. The data provided information that the learning process had been emphasized activity-based learning so that student activity is in the category very good.

Referring to Dierich's opinion in Sardiman (2014: 101), the expected indicator of student activity success has emerged as the indicator points of each criterion in the application of CPS Version 2.2. Student activities that have been seen in the learning process are as follows.

Students' visual activity occurred when students make observations on pictures presented to collect preliminary information; make direct observations to collect factual information; make observations on the pictures presented to collect the information on the cause of the problem; find alternative solution ideas from the given picture; and when students find an alternative idea of a solution from a given text.

Students' oral activity occurred when the students create their own question of their curiosity referring to the given topic; participate in group discussion process to find answers; look for causes of problems that exist through group discussions; formulate the main problem found; find alternative solutions ideas freely and independently; create a joint rule (contract agreement) before starting the implementation; do reflection by answering questions from the teacher; evaluate the implementation of solutions based on their benefits and losses; and when students make conclusions based on the results of reflection and evaluation.

Students' listening activity was seen when students participate in a group discussion process to find answers; look for causes of problems that exist through group discussions; formulate the main problem found; find alternative solutions ideas freely and independently; create a joint rule (contract agreement) before starting implementation); do reflection by answering questions from the teacher; evaluate the implementation of solutions based on their benefits and losses; and when students make conclusions based on the results of reflection and evaluation.

Students' writing activity occurred when students register factual information obtained; reconstruct some object of observation that he deems problematic; find alternative solutions ideas freely and independently; complete the table with all alternative ideas of solutions found; create action plans; compile the items of action; do reflection by answering questions from the teacher; evaluate the implementation of solutions based on their benefits and losses; and when students 
make conclusions based on the results of reflection and evaluation.

Students' motor activity occurred when students select the object of observation that is considered problematic; select problems that are most likely to be addressed immediately; perform analytical techniques to select alternative ideas for the solution; find the best solution based on the analytical techniques that have been done; analyze again from some of the best solutions found by each group; agree on the best solution choice of class; and when students implement the best solution in a mutual way. The increased student activities are presented in Figure 1.

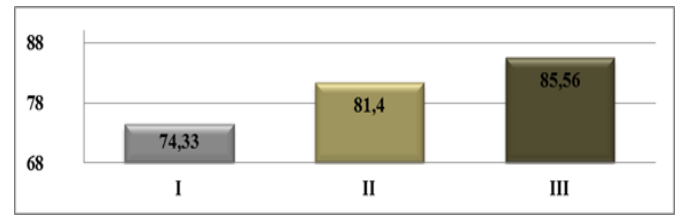

FIGURE 1.

GRAPH OF AVERAGE RESULT OBSERVATION OF STUDENTS' ACTIVITY FROM CYCLE I-III

Remark:

I = Students' activity in cycle I

II = Students' activity in cycle II

III = Students' activity in cycle III

In accordance with Vygotsky's theory, (Mahn, 2012) ZPD allowed students to be able to expand the ZPD area. Learning using the CPS Version 2.2 lets students expand the ZPD area due to the limited guidance process as the beginning of each stage and then trained bit by bit to be trained independently through the collaboration process. Students are given the confidence to go through each process by expressing ideas as much as possible until selecting the best solution and applying it.

Based on Ausabel's meaningful learning theory (Illeris \& Knud, 2015) which emphasizes the importance of students' association with new experiences, phenomena, and facts into the system of understanding they already have, and in the learning process the students must be active. Therefore, learning with the CPS Version 2.2 emphasized student activeness independently to find solutions and implement them.

\subsection{Student Achievement}

To overcome the problem of the low achievement students at knowledge and skill domain, students are trained to do the thinking process of divergent/creative and convergent/critical to solve the contextual social problems which exist at school, then students must implement the solutions found. Students' achievements (knowledge domain) are presented in Figure 2

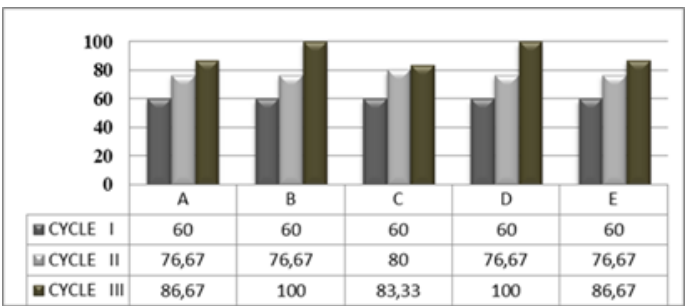

FIGURE 2. STUDENTS' ACHIEVEMENT (KNOWLEDGE DOMAIN) FROM CYCLE I-III

Remark:

A =Students' achievement of PPKn content

B =Students' achievement of Bahasa Indonesia content

C =Students' achievement of Mathematics content

D =Students' achievement of SBdP content

$\mathrm{E}=$ Students' achievement of PJOK content

When students are trained on tests to solve social problems in the integrity of five lessons on the behavior of clean and healthy life at school, it will improve students' cognitive achievements which are reflected through the ability to think to solve every problem faced. The problem solving was done through learning groups by analyzing problems in everyday life so that students became more active in thinking and doing activities.

Thus, referring to Bruner's constructivist view (Jian \& Perkins, 2013), cognitive maturation process, namely: cognitive growth is indicated by the increased dependence of the response to the stimulus. In this case, the students' dependence on the picture media as stimulus will begin to decrease when the students directly interact with their environment contextually. Students' achievements (skill domain) are presented in Figure 3.

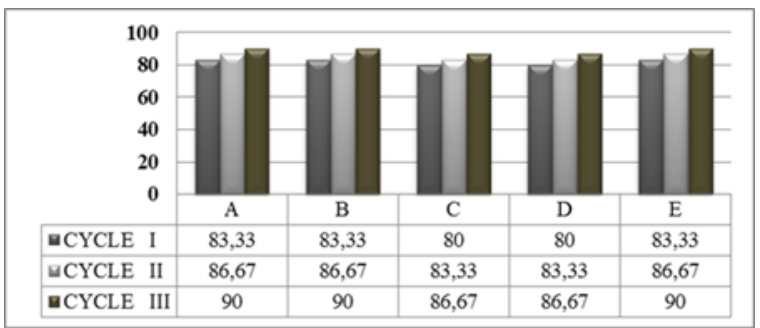

FIGURE 3. STUDENTS' ACHIEVEMENT (SKILL DOMAIN) FROM CYCLE I-III

Remark:

A = Students' achievement of PPKn content

$\mathrm{B}=$ Students' achievement of Bahasa Indonesia content

$\mathrm{C}$ = Students' achievement of Mathematics content

D = Students' achievement of SBdP content

$\mathrm{E}=$ Students' achievement of PJOK content 
Referring to the behavioral approach, undisciplined behavior can be avoided and may lead to good behavior (Thorndike and Skinner in Dahar, 2011). This approach saw affirmation as forming a very memorable behavior. Affirmation in the application of CPS Version 2.2 was the opportunity for students to reflect, conclude, and evaluate the execution of the implementation of the solution that has been done by the students themselves.

Behavioral theory believes in a person's behavior shaped by experience (Hamilton, 2007). Therefore, through the execution of the solution implementation to social problems related to clean and healthy life behavior, the student had passed a process of experience that impressed on the students' achievement in behaving according to the expected target of competence.

Based on the results of observations, students' skill achievement had been able to overcome the problem of very low students' activity in behaving on clean and healthy life even tended not to care and had less responsibility. However, it was overcome not by going through doctrinization but a process of learning to know, realize, find solutions, and solve social problems related to clean and healthy life behavior at school.

Students' learning outcomes reflected the demands on Permendikbud No. 20 of 2016 on the Competency Standards of Primary and Secondary Education graduates. In the knowledge dimension: students were able to link knowledge at school context; have factual knowledge in the form of basic knowledge to solve social problems about clean and healthy life behavior at schools; possess conceptual knowledge through the ability to classify and categorize facts, problems, ideas, and solutions; possess procedural knowledge in the form of knowledge of how to carry out the implementation activities of found solutions; as well as have metacognitive knowledge in the form of reflection and evaluation activities after executing the solution. In the skill dimension: students had the skills of thinking and acting according to the stage of child development creatively, productively, critically and independently

\section{CONCLUSION}

Basically, problem-solving skills using CPS Version 2.2 for second-grade students is a stage of recognition and habituation with every information they can understand in a pleasant atmosphere. It will be very useful as the initial foundation of students to be familiar with high order thinking skills that are also expected to be able to have good adaptation skills, able to find alternatives and better social skills.

The result of the research showed that students' activity may increase in each cycle as well as students' achievements can be improved in both domains. The improvement of students' knowledge competency through student activity to solve social problem around students' contextual environment implemented in action to execute solution right away, therefore, students' skill competency can be improved as a proof of awareness and caring autonomously

\section{REFERENCES}

[1] Dahar, R.W., 2011. Teori belajar dan pembelajaran. Jakarta: Erlangga.

[2] Fogarty, R., 1991. How to integrated the curricula. Illinois: Skylight Publishing Inc, Palatine.

[3] Hamilton, V., 2007. Human relations: The art and science of building effective relationships. Pearson/Prentice Hall.

[4] Illeris, K., 2015. The development of a comprehensive and coherent theory of learning. European Journal of Education, 50(1), pp.29-40.

[5] Jiang, X. and Perkins, K., 2013. A Conceptual Paper on the Application of the Picture Word Inductive Model Using Bruner's Constructivist View of Learning and the Cognitive Load Theory. Interdisciplinary Journal of Teaching and Learning, 3(1), pp.8-17.

[6] Mahn, H., 2012. Vygotsky's analysis of children's meaning making processes. International Journal of Educational Psychology, 1(2), pp.100-126.

[7] Mitchell, W.E. and Kowalik, T.F., 1999. Creative problem solving. Retrieved on April, 4, p.2004.

[8] Sardiman, A.M., 2000. Interaksi \& motivasi belajar mengajar. PT RajaGrafindo Persada.

[9] Soeharto, K., 2003. Teknologi Pembelajaran Pendekatan Sistem, Konsepsi dan Model, SAP, Evaluasi, Sumber Belajar dan Media. Surabaya. Sic, pp.80-82.

[10] Treffinger, D.J. and Isaksen, S.G., 2005. Creative problem solving: The history, development, and implications for gifted education and talent development. Gifted Child Quarterly, 49(4), pp.342-353.

[11] [11] Kandemir, Ali Mehmet dan Hulya Gur. 2009. The use of creative problem solving scenarios in mathematics education: views of some prospective teachers http://coral.ufsm.br/righi/EPE/CPS/The_use_of_creative_problem_solvi ng_scenarios_in_m.pdf

[12] [12] Samsons, Patricia L. 2015. Fostering Student Engagement: Creative Problem- Solving in Small Group Facilitations. https://files.eric.ed.gov/fulltext/EJ1069715.pdf

[13] [13] Alghamdi, Amani K.H. 2017. The Effects of an Integrated Curriculum on Student Achievement in Saudi Arabia. http://www.ejmste.com/The-Effects-of-an-Integrated-Curriculum-onStudent-Achievement-in-Saudi-Arabia,75573,0,2.html 